\title{
HUBUNGAN ANTARA LAMA HARI RAWAT DENGAN ANTRIAN MASUK RUMAH SAKIT PADA PASIEN BPJS DI RS. ISLAM JEMURSARI SURABAYA
}

\author{
Agustina Ekawati, Wiwik Afridah \\ Universitas Nahdlatul Ulama Surabaya - Jl Jemursari 51- 57 Surabaya \\ Email : wiwik@gmail.ac.id
}

\begin{abstract}
Since January to December, visits BPJS patients in Jemursari Islamic hospital increased average of 241 patients per month. On 27 December 2014 have an survey with ten BPJS patiens who $80 \%$ must waiting for the room. The purpose of this research is to find out the relation of the inpatiets waiting list with the long of BPJS inpatient who was gived the treatment in Jemursari Islamic hospital Surabaya.

The design is cross-sectional analytic probability sampling is simple random sampling . The population of inpatient in Islamic hospital Surabaya are 181 people, for sample are 73 BPJS patients hospitalized in Jemursari Islamic Hospital Surabaya, being 73 ALOS of BPJS patients secondary data taken from medical records. The independent variable is the long of stay with instument is the secondary data from medical record and the dependent variable of the queue inpatient with the research instrument using questioner.

The results showed long of stay or BPJS patient ALOS majority (74.0\%) patients were not standardized, and almost all $(85.0 \%)$ BPJS patients queuing to enter the hospital. The Fisher's Exact Test statistical shows that $p=0,029$ and $p<a=0,05$ means HO is rejected, there is relationship long of stay with the queue BPJS patient in Jemursari islamic Hospital Surabaya

The conclusion of this research is if the long of stay not standard with the queue of BPJS patient is getting more. Because of the reason, the hospital is expected to more optimalizing the long of stay of inpatient or give more bed.
\end{abstract}

Keywords : long of stay, queues, BPJS patient

Abstrak. Sejak bulan Januari sampai dengan Desember, kunjungan pasien BPJS di RS Islam Jemursari meningkat rata - rata 241 pasien perbulan. Berdasarkan survey di RS Islam Jemursari pada tgl 27 Desember 2014 pada 10 pasien BPJS, didapatkan 80\% pasien mengantri. Tujuan penelitian mengetahui hubungan antrian rawat inap dengan lama hari rawat pasien BPJS di RSI Jemursari Surabaya.

Desain penelitian cross sectional probability sampling yaitu secara simple random sampling. Populasi sebanyak 181 orang dengan sampel 73 pasien BPJS yang rawat inap di RS Islam Jemursari Surabaya, 73 ALOS dari pasien BPJS diambil dari data sekunder rekam medis. Variabel bebas adalah lama hari rawat, instrument adalah data sekunder dari rekam medis RS Islam Jemursari dan variabel tergantung adalah antrian masuk rumah sakit dengan instrumen penelitian menggunakan lembar kuesioner.

Hasil penelitian didapatkan lama hari rawat atau ALOS pasien BPJS sebagian besar $(74,0 \%)$ pasien tidak standar, dan hampir seluruhnya $(85,0 \%)$ pasien BPJS antri untuk masuk rumah sakit. Uji statistik Fisher's Exact Test, didapatkan $\rho=0,029$ berarti $\rho<\alpha=0,05$ artinya $\mathrm{H0}$ ditolak, ada hubungan antara lama hari rawat dengan antrian masuk rumah sakit pada pasien BPJS diRS Islam Jemursari Surabaya

Jika lama hari rawat tidak standar maka pasien BPJS antri semakin banyak. Oleh sebab tersebut diharapkan rumah sakit lebih mengoptimalkan lama hari rawat pasien atau menambah bed.

Kata kunci : lama hari rawat, antrian , pasien BPJS 


\section{PENDAHULUAN}

Sejak diluncurkannya program BPJS (Badan Penyelenggara Jaminan Sosial) oleh pemerintah pada bulan Januari 2014 dengan sistem berjenjang maka setiap rumah sakit memiliki kesempatan untuk mendapatkan rujukan pasien BPJS sehingga bisa meningkatkan angka kunjungan pasien. Salah satu rumah sakit Type B yang memiliki kesempatan tersebut adalah RS Islam Jemursari, dengan adanya BPJS, kunjungan untuk rawat inap pasien BPJS di RS Islam Jemursari meningkat, hal ini dapat ditunjukkan pada tabel berikut ini:

\begin{tabular}{|c|c|c|}
\hline \multicolumn{3}{|c|}{$\begin{array}{l}\text { Perbandingan jumlah pasien berdasarkan } \\
\text { cara bayar (UMUM DENGAN BPJS) }\end{array}$} \\
\hline \multicolumn{3}{|c|}{\begin{tabular}{|l|l|l} 
BULAN & Umum & BPJS
\end{tabular}} \\
\hline Februari & 3053 & 1806 \\
\hline Maret & 3198 & 1715 \\
\hline April & 3366 & 2276 \\
\hline Mei & 3278 & 2746 \\
\hline Juni & 3192 & 2851 \\
\hline Juli & 2496 & 2643 \\
\hline Agustus & 3085 & 3638 \\
\hline September & 3359 & 4609 \\
\hline Oktober & 3296 & 4876 \\
\hline November & 3396 & 4879 \\
\hline Desember & 3409 & 5737 \\
\hline
\end{tabular}

Tabel 1 : Perbandingan Jumlah Pasien Umum dan BPJS di RS Islam Jemursari 2014

Data rekam medis di Rumah sakit Islam Jemursari yang diambil pada tanggal 15 September 2014 menunjukkan bahwa BOR rumah sakit pada bulan Januari sampai dengan Desember rata - rata 57\%, dengan rincian pada triwulan pertama bulan Januari - Maret 2014 dengan ratarata BOR (Bed Ocupancy Rate) 46,84\% dengan standart hari rawat 6-9 hari didapatkan lama hari rawat ALOS (Average Lenght On Stay) 0,34\%, trimester kedua bulan April - Juni 2014 dengan BOR 57,99\% didapatkan ALOS $0,33 \%$, trimester ketiga bulan Juli -
September dengan rata-rata BOR (Bed Ocupancy Rate) $54,73 \%$ didapatkan ALOS (Average Lenght On Stay) 0,55\% dan pada trimester keempat bulan Oktober - Desember dengan rata-rata BOR (Bed Ocupancy Rate) $65,53 \%$ didapatkan ALOS (Average Lenght On Stay) 0,63\% dan berdasar 10 kasus penyakit kronis terbanyak rata - rata didapatkan lama hari rawat 2,3-14,0, berdasarkan data diatas didapatkan kesimpulan bahwa lama hari rawat masih panjang termasuk pasien BPJS, walaupun pasien BPJS menggunakan sistem Indonesia Case Base Group`s (INA CBG'S) yang berarti pembayaran biaya seorang peserta mengacu pada diagnose.

Rekam medis rumah sakit dari bulan Januari sampai dengan Juni 2014, masih didapatkan $35 \%$ pasien BPJS dirujuk karena kamar penuh. Berdasarkan survey di RS Islam Jemursari pada tgl 27 Desember 2014 ada 10 pasien BPJS, didapatkan $80 \%$ pasien mengantri untuk mendapatkan kamar sesuai haknya.

Suara Merdeka, 8 Juli 2014, di RS Karyadi, seringkali kewalahan mengatasi masalah pasien daftar tunggu. Jumlah daftar tunggu pasien VIP hingga kelas III tercatat mencapai 900 orang. Natalia.com menyebutkan slot kamar rawat inap di RSKD untuk BPJS selalu penuh, jadwal operasi tergantung kapan ada kamar yang kosong dulu supaya bisa masuk opname. Jadwal operasi baru disesuaikan segera setelahnya, total masa menunggu kami, kira-kira tiga minggu lamanya. Sementara Nuansa Baru menjelaskan "Antrian panjang rawat inap dirumah sakit Darmais memunculkan ide penambahan jumlah tempat tidur harus menjadi "Crash Program" dan prioritas utama pembangunan bidang kesehatan. Besaran biaya PBI (Penerima Bantuan Iuran) harus segera direvisi dan dinaikan jumlahnya, agar fasiltas kesehatan dan rumah sakit swasta dapat terlibat secara maksimal dalam program BPJS Kesehatan. Harian terbit.com, mengungkap antrian pasien ICU sudah diluar batas kewajaran. Hal ini 
terjadi akibat adanya program BPJS Kesehatan. Berdasarkan data tersebut diatas RS Islam Jemursari dituntut untuk dapat memenuhi kapasitas atau menambah jumlah tempat tidur sesuai dengan hak pasien misalnya peningkatan kunjungan dikelas - kelas tertentu atau bisa pula lebih memperhatikan lama hari perawatan untuk kasus dengan diagnose tertentu serta bisa membuat sistem antrian pasien lebih baik tanpa harus mengantri lama untuk mendapatkan ruang perawatan. Untuk mencapai semua diatas maka perlu dilakukan penelitian tentang hubungan antara lama hari rawat, dengan antrian masuk rumah sakit di RS Islam Jemursari. Surabaya, sehingga hasil yang ada dapat memberikan masukan bagi RS Islam Jemursari Surabaya untuk dijadikan acuan sebagai rencana kerja selanjutnya untuk meningkatkan mutu pelayanan rumah sakit.

\section{METODE}

Desain yang digunakan dalam penelitian ini adalah jenis analitik Sedangkan rancangan yang digunakan adalah cross sectional Populasi penelitian adalah semua pasien dari berbagai ruangan rawat inap dengan berbagai diagnosa di RS Islam Jemursari Surabaya sebesar 181 (rata-rata kunjungan pasien rawat inap 6 bulan terakhir Februari- Juli). Sampel dalam penelitian ini sebesar 73. Menggunakan teknik probability sampling yaitu secara simple random sampling. Variabel dalam penelitian ini meliputi dua variabel, yaitu : Lama hari rawat dan Antrian masuk rumah sakit. Instrumen yang digunakan untuk mengukur lama hari rawat adalah penghitungan lama hari rawat ALOS (Average Lenght on Stay), dan kuesioner. dianalisis dengan menggunakan uji statistik Fisher`s exact test.

\section{Hasil Penelitian}

a. Karakteristik responden berdasarkan $A L O S$

Tabel 2. Distribusi frekuensi responden berdasarkan ALOS pasien BPJS di RS Islam Jemursari Surabaya pada bulan November Desember 2014

\begin{tabular}{cccc}
\hline No & ALOS & $\begin{array}{c}\text { Frekuensi } \\
(\mathrm{f})\end{array}$ & $\begin{array}{c}\text { Persentase } \\
(\%)\end{array}$ \\
\hline 1 & Standar & 19 & 26,0 \\
2 & Tidak & 54 & 74,0 \\
& standar & & \\
\hline \multicolumn{2}{c}{ Jumlah } & 73 & 100 \\
\hline
\end{tabular}

Sumber : Data primer, 2015

Berdasarkan table 2. menunjukkan sebagian besar $A L O S(74,0 \%)$ pasien tidak standar.

b. Karakteristik responden berdasarkan antrian

Tabel 3. Distribusi frekuensi responden berdasarkan antrian pasien BPJS di RS Islam Jemursari Surabaya bulan November

Desember2014

\begin{tabular}{cccc}
\hline No & Antrian & $\begin{array}{c}\text { Frekuensi } \\
(\mathrm{f})\end{array}$ & $\begin{array}{c}\text { Persentase } \\
(\%)\end{array}$ \\
\hline 1 & Antri & 62 & 85,0 \\
2 & Tidak & 11 & 15,0 \\
& Antri & & \\
\hline \multicolumn{2}{c}{ Jumlah } & 73 & 100 \\
\hline
\end{tabular}

Sumber : Data primer, 2015

Berdasarkan tabel 3. menunjukkan hampir seluruhnya $(85,0 \%)$ pasien BPJS antri jika hendak masuk rumah sakit.

Tabel 4. Tabulasi silang hubungan antara lama hari rawat dengan antrian masuk rumah sakit pada pasien BPJS di RS Islam Jemursari Surabaya. Pada bulan November - Desember 2014 


\begin{tabular}{|c|c|c|c|c|c|c|c|}
\hline \multirow[t]{3}{*}{ No } & \multirow[b]{3}{*}{$\begin{array}{c}\text { Lama Hari } \\
\text { Rawat }\end{array}$} & \multicolumn{4}{|c|}{ Antrian } & \multirow{2}{*}{\multicolumn{2}{|c|}{ Jumlah }} \\
\hline & & \multicolumn{2}{|c|}{ Antri } & \multicolumn{2}{|c|}{$\begin{array}{l}\text { Tidak } \\
\text { Antri }\end{array}$} & & \\
\hline & & $\mathrm{N}$ & $\%$ & $\mathrm{~N}$ & $\%$ & $\mathrm{~N}$ & $\%$ \\
\hline 1 & \multirow{2}{*}{$\begin{array}{l}\text { ALOS standar } \\
\text { ALOS tidak } \\
\text { standar }\end{array}$} & 13 & 20,96 & 49 & 79,03 & 62 & 100 \\
\hline \multirow[t]{2}{*}{2} & & 6 & 54,54 & 5 & 45,45 & 11 & 100 \\
\hline & Jumlah & 19 & 26,02 & 54 & 73,97 & 73 & 100 \\
\hline & ishor's & & $=0$, & & & & \\
\hline
\end{tabular}

Tabel 5. menunjukkan bahwa sebagaian besar 62 pasien BPJS dengan lama hari rawat standar hampir seluruhnya 79,03\% tidak antri, dari sebagian kecil 11 pasien BPJS dengan lama hari rawat tidak standar sebagian besar $54,54 \%$ antri.

Hasil analisis di dapatkan $\rho=0,029$ berarti $\rho<\alpha=0,05$, sehingga dapat disimpulkan $\mathrm{H}_{0}$ di tolak yang berarti ada hubungan antara lama hari rawat dengan antrian pasien BPJS di RS Islam Jemursari Surabaya.

\section{PEMBAHASAN}

\section{Lama hari rawat}

Tabel 2. menunjukkan bahwa lama hari rawat atau ALOS pasien BPJS 74\% artinya sebagian besar lama hari rawat pasien tidak standar, walau lama hari rawat pasien BPJS tidak ditentukan berdasar berapa lama dia menginap melainkan mengacu pada diagnosa. Semakin lama pasien dirawat tidak menambah paket biaya pasien BPJS walaupun diagnosa sesuai INA CBG's hal ini akan menimbulkan kerugian bagi rumah sakit. Pelayanan medis di RS Islam Jemursari hanya memiliki 6 dokter spesialis tetap sedangkan dokter spesialis tamu belum semua bersedia menerima pasien BPJS sehingga jumlah pasien BPJS yang rawat inap rata- rata 100-150/hari tidak sesuai dengan dokter yang ada. Dengan adanya hal tersebut RS Islam jemursari berusaha menambah jumlah dokter tetap, sementara penambahan dokter tetap hanya untuk kasus tertentu dengan jumlah kunjungan banyak seperti spesialis jantung, spesialis anak, spesialis urologi dan spesialis bedah.
Jika kamar pasien BPJS yang sesuai haknya penuh, maka rumah sakit membuat kebijakan pasien bisa naik kelas sampai dengan 3 hari tanpa penambahan biaya, jika sampai dengan hari ke tiga kamar belum ada maka pasien harus membayar selisih biaya atau dirujuk sesuai hak kelas BPJS di rumah sakit provider BPJS. Pelayanan medis sangat berpengaruh pada proses perawatan pasien sehingga menentukan lama hari rawat pasien tersebut (Djoko wijono, 2000). Kondisi fisik pasien dengan sistem imun yang buruk dimana sistem pertahanan manusia terhadap infeksi dari makromolekul asing atau serangan virus, bateri, protozoa, dan parasit terganggu karena penyakit imun sehingga tubuh tidak dapat membentuk anti bodi yang akhirnya memperlama proses penyembuhan bahkan memunculkan penyakit baru. (biobloguphc.wordpress.com). Dari 10 besar penyakit utama di RS Islam Jemursari $60 \%$ merupakan penyakit kronis dengan $(45,2 \%)$ hampir setengahnya pasien berusia $41-65$ tahun yang memerlukan penanganan lanjutan di rumah sakit antara lain penyakit jantung, hipertensi, gagal ginjal, kencing manis, TB paru dan infeksi saluran kencing non spesifik, 20\% diare beserta kurang cairan, $10 \%$ kasus orthopedi dan $10 \%$ kasus auto imun. Penyakit kronis dengan diagnosa tertentu, yang mempunyai karakteristik menetap, meninggalkan cacat, patologis yang tidak kembali, memerlukan training khusus untuk rehabilitasi membutuhkan perawatan yang lama (wrigt \& leahey, 1987).

2. Antrian masuk rumah sakit

Tabel 3. menunjukkan hampir seluruhnya pasien BPJS masuk RS Islam Jemursari harus antri. Walaupun system antrian di rumah sakit menganut Multi Chanel Multi Phase, sistem ini terjadi jika ada dua atau lebih fasilitas pelayanan dengan pelayanannya lebih dari satu phase yang mana pasien di rumah sakit dari pendaftaran, diagnosa, tindakan medis sampai pembayaran mempunyai beberapa 
fasilitas pelayanan pada setiap tahap, sehingga lebih dari satu individu dapat dilayani pada suatu waktu.(Silanungga, 2008:249) sedang menurut Wagner (1972:840), pola kedatangan adalah pola pembentukan antrian akibat kedatangan customer dalam selang waktu tertentu. Berdasarkan temuan kasus antrian di RS Islam Jemursari pada pasien BPJS dikarenakan kartu peserta belum bisa digunakan atau tidak aktif (tidak terdaftar di sistem on line BPJS). Mengingat, berdasarkan peraturan yang baru kartu pasien baru bisa berlaku (aktif) setelah hari ke-8 terdaftar dan sudah membayar iuran (Peraturan direksi BPJS Kesehatan No.211 thn2014) dan rujukan tidak sesuai persyaratan paket INA CBG`s, yang seharusnya untuk masuk rumah sakit type b harus sudah membawa rujukan dari puskesmas/dokter praktek (PPK 1) yang sudah distempel BPJS, jika tidak ada maka SEP (surat elijibilitas peserta) tidak bisa diterbitkan, yang akhirnya tidak ditanggung BPJS. Persepsi masyarakat selalu mengira semua kasus bisa ditangani di rumah sakit dengan menggunakan BPJS, hal ini karena keputusan peraturan yang masih berubah - ubah setiap waktu dari BPJS pusat dan belum terdokumentasi dan tersosialisasikan dengan baik. Untuk mengatasi hal tersebut selain informasi penerimaan BPJS dan alur lewat spanduk, baner, di monitor antrian dan loket pendaftaran RS Islam Jemursari selalu ter update info - info tentang tata tertib pasien BPJS. Antrian bisa juga terjadi karena tidak adanya ketersediaan kamar, ketersediaan sarana bed untuk kelas tiga dan kelas dua selalu penuh, hal ini dibuktikan dengan hasil penelitian hampir seluruhnya $(85,0 \%)$ pasien BPJS antri jika hendak masuk rumah sakit dengan rincian antrian : pasien antri di kelas I sebanyak 7 orang, kelas II sebanyak 18 orang dan kelas III sebanyak 37 orang. Sedangkan prasarana medis untuk jadwal operasi kamar operasi juga selalu penuh, ICU dengan 6 respirator juga selalu penuh, sedangkan pemeriksaan penunjang seperti
MRI, endoscopy, lab PA masih harus dikirim keluar karena sarana yang ada masih baru. Oleh karenanya, diperlukan penambahan fasiltas, sarana dan prasarana terkait adanya peningkatan layanan terhadap pasien, baik peserta BPJS maupun non BPJS.

3. Hubungan antara lama hari rawat dengan antrian pasien BPJS

Hasil penelitian didapatkan bahwa terdapat hubungan antara lama hari rawat dengan antrian pasien BPJS di RS Islam Jemursari Surabaya. Rata - rata kunjungan di RS Islam Jemursari adalah pasien umum 20\%, pasien asuransi/instansi $20 \%$ dan BPJS $60 \%$ dengan rincian kunjungan rawat inap di IGD rata- rata 28 pasien perhari dan rawat jalan dengan rata - rata 15 pasien perhari menambah panjang daftar antrian masuk rumah sakit karena belum semua pasien bisa terlayani khususnya antrian di kelas II dan III dengan diagnosa hipertensi, diabetes mellitus, bronkopneumoni, gagal ginjal dan infeksi saluran kencing yang masih harus antri karena layanan melebihi kemampuan (kapasitas) pelayanan. Untuk mendapatkan pelayanan, pasien elektif harus melakukan pendaftaran dahulu dilengkapi persyaratan tertentu. Pasien yang membayar jasa layanan secara tunai tentu berbeda persyaratannya dengan pasien jaminan/asuransi sehingga waktu pendaftaran dan antrian masuk rumah sakitpun membutuhkan waktu antri yang berbeda (Anjari umarjianto, 2013). Priority service (PS) adalah antrian kepada mereka yang mempunyai prioritas paling tinggi dibandingkan dengan mereka yang memiliki prioritas paling rendah, meskipun yang terakhir ini sudah lebih dahulu tiba dalam garis tunggu dalam hal ini yang diterapkan di RS Islam Jemursari dan menjadi acuan pelayanan untuk menangani antrian di IGD ( Instalasi Gawat darurat) adalah triage. Keefektifan tingkat pemakaian bed yang berhubungan dengan lama dirawat pasien akan mempengaruhi perhitungan lama hari rawat. (Rano 
Indradi, 2007). Lama hari rawat pasien BPJS sesuai dengan paket INA CBG`s (Indonesia Case Base Group`s), sesuai dengan diagnosa pasien yang di koding mulai diagnosa awal dan didapatkan hasil saat muncul diagnosa akhir waktu pasien dinyatakan sembuh/dirujuk dan keluar rumah sakit ( ASKES, 2014).

\section{SIMPULAN}

Berdasarkan data penelitian yang telah dilakukan maka dapat disimpulkan sebagai berikut :

1. Pasien BPJS di RS Islam Jemursari Surabaya sebagian besar lama hari rawatnya tidak standar antara $<3$ dan $>12$ hari.

2. Pasien BPJS di RS Islam Jemursari Surabaya hampir seluruhnya masih antri saat masuk rumah sakit.

3. Ada hubungan antara lama hari rawat dengan antrian masuk rumah sakit pasien BPJS diRS Islam Jemursari Surabaya.

\section{DAFTAR PUSTAKA}

Arikunto, Suharsimi. (2006). Prosedur Penelitian Suatu Pendekatan Praktek. Jakarta, RinekaCipta

ASKES (2014). Pedoma pelayanan BPJS per 1 Januari 2014, PT.ASKES 1 Januari 2014

Bioblogup (2015). Sistem Imun.diunduh 2 Februari 2015

Depkes RI (1997). Pedoman Pengelolaan Rekam Medis Rumah Sakit Di Indonesia. Jakarta, Depkes RI Direktorat Jenderal Pelayanan medik

Donaldson, Thomas (2001). Future Customer. Surabaya, Selasar Publishing

Harian terbit.com (2014) Daya tampung RSUD bekasi overload. diunduh selasa 23 Desember 2014.
Indradi Sudra, Rano (2010) Statistik Rumah Sakit. Yogyakarta, Graha ilmu

Kamus Kesehatan.com (2015).Triage, diunduh 2 Februari 2015

Kompas. Com (2013). Sistem One Day Care di RS dr. Moh. Saleh Probolinggo.www.kompas.com diunduh jum`at 12 September 2014

Kotler, Philip (2009). Manajemen Pemasaran. Jakarta, Erlangga

Kotler, Philip (2005). Marketing Manajemen. Jilid 1 Edisi Kesebelas Bahasa Indonesia. Jakarta, Indeks

Majalah Kedokteran andalas, (2008). Lama Hari Rawat Diare. www.mka .fk.unand.ac.id diunduh Jum`at 12 September 2014

Moleong, Lexi J (2004). Metodologi Penelitian Kualitatif. Bandung, PT Remaja Rosdakarya

Natalia.com (2014). Cerita di balik cerita, diunduh selasa 23 Desember 2014.

Notoatmodjo (2012). Metodologi Penelitian Kesehatan. Jakarta, Rineka Cipta

Nuansa baru indonesia(2014). Antrian panjang di RSCM dan RS Dharmais, diunduh selasa 23 Desember 2014.

Nursalam, (2013) Metodologi Penelitian Ilmu Keperawatan, Edisi 3. Surabaya, Salemba Medika

Rano, (2013). Antara Lama Dirawat \& Hari perawatan. www.rano center.net diunduh Senin 8 September 2014

Setiawan, SatrioAdi. (2010). Pengaruh Umur, Pendidikan, Pendapatan, Pengalaman Kerja Dan Jenis Kelamin. 
http://eprints.undip.ac.id.Diakses

tanggal 16 Desember 2014

Sinalungga (2008) Sistem Antrian Rumah

Sakit, Makalah teori antrian, di unduh

2 Februari 2015

SK Gubernur Jatim(2014). Surat edaran dan pelaksanaan program JKN dan Jamkesda th 2014, Gubernur Jatim 31 Desember 2013

SK Gubernur Jatim(2015). Surat edaran dan pelaksanaan program JKN tentang masa berlaku kartu, Gubernur Jatim 1 Januari 2015

Soejadi (2010). Efisiensi Pengelolaan Rumah Sakit. Jakarta Apikes

Suara Merdeka.Com (2014). RS Kariadi Resmikan Rumah Singgah. www.suara merdeka.com diunduh Senin, 22 September 2014

Sugiyono (2013). Metode Penelitian Kuantitatif Kualitatif Dan $R$ \& D. Bandung, Alfabeta

Supranto \& Limakrisna, Nandan (2012). Skripsi Tesis Dan Disertasi

Supriyanto, S (2010). Manajemen Mutu Administrasi dan Kebijakan Kesehatan. Surabaya, Airlangga

TIM Rekam Medis RS Islam Jemursari Surabaya (2011). Laporan Indikator Pelayanan RS Islam Jemursari Surabaya. Surabaya, RM

Tjiptono (2006).Perspektif Manajemen dan Pemasaran Kontemporer. Yogjakarta, Nuha Medika

Wijono, Djoko (2000). Manajemen Mutu Pelayanan Kesehatan. Vol 2. Surabaya, Airlangga University Press 